\title{
Irish Labour and the Home Rule question,
}

\section{1-1914}

Le Mouvement ouvrier irlandais et la question de l'autonomie, 1881-1914

\section{Emmet O'Connor}

\section{(2) OpenEdition}

Journals

Electronic version

URL: http://journals.openedition.org/rfcb/3747

DOI: $10.4000 /$ rfcb.3747

ISSN: 2429-4373

\section{Publisher}

CRECIB - Centre de recherche et d'études en civilisation britannique

\section{Electronic reference}

Emmet O'Connor, «Irish Labour and the Home Rule question, 1881-1914 », Revue Française de Civilisation Britannique [Online], XXIV-2 | 2019, Online since 19 June 2019, connection on 09 July 2019. URL : http://journals.openedition.org/rfcb/3747 ; DOI : 10.4000/rfcb.3747

This text was automatically generated on 9 July 2019.

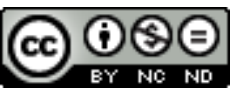

Revue française de civilisation britannique est mis à disposition selon les termes de la licence Creative Commons Attribution - Pas d'Utilisation Commerciale - Pas de Modification 4.0 International. 


\section{Irish Labour and the Home Rule question, 1881-1914}

Le Mouvement ouvrier irlandais et la question de l'autonomie, 1881-1914

\section{Emmet O'Connor}

\section{Introduction}

1 The Home Rule question dominated Irish politics between the 1870s and the Easter Rising of 1916. While three quarters of Irish people wanted self-government, they were opposed fiercely by supporters of the Union with Britain, who had the advantages of being almost entirely Protestant in a state and society which routinely discriminated against Catholics, concentrated to form a majority in Ulster, and backed by the powerful British Conservative Party. The two most important Labour representative bodies in contemporary Ireland were Belfast trades council and the Irish Trades Union Congress (ITUC). ${ }^{1}$ The Home Rule issue presented both with an abiding, if indirect, problem. As the nineteenth century progressed, Belfast evolved from a town of some 20,000 people into a major centre of manufacture with, in 1911, almost 387,000 souls, making it almost the biggest city in Ireland. In the process, its fortunes diverged from the southern provinces, where manufacture and population suffered steady decline. In 1907, the Belfast region accounted for $£ 19.1$ million of Ireland's $£ 20.9$ million worth of manufactured exports, excluding food and drink. This performance was based mainly on a high degree of specialisation within the British economy, especially in textiles, engineering, and shipbuilding, so that Belfast's industrial links were primarily with Britain rather than the south. ${ }^{2}$ Moreover, Belfast was about seventy-five per cent Protestant and Unionist. The two main Unionist arguments were that Home Rule would mean Rome rule and a Dublin parliament would introduce tariffs and destroy the free trade on which Belfast's prosperity had been built.

2 Tariffs were indeed a nationalist objective. From the emergence of Daniel O'Connell's campaign to Repeal the Act of Union in 1830, trade unions in the south of Ireland had been openly nationalist, convinced that self-government and tariff protection were 
essential to arrest de-industrialization and effect an economic recovery. Formed in 1894, the ITUC was technically a breakaway from the British Trades Union Congress, which had been established in 1868 as a 'parliament of labour' for the entire United Kingdom. Its inaugural manifesto hinted at a parallel with the Home Rule question.

Like the Imperial Parliament, the [British] Congressional machine has become overladen with the multifarious duties and interests committed to its care...they cannot be expected to understand the wants of a community largely agricultural, nor can we hope that they would, so to speak, cut their own throats, by assisting in reviving the languishing manufactures of Ireland. ${ }^{3}$

The mask had slipped, briefly. This was old thinking. New thinking led both Belfast trades council and the ITUC to forbid discussion of "politics", by which was meant things to do with the constitutional question. In the approving words of a Belfast delegate, "As a Trades Congress they knew nothing about religion or politics... ." In practice, the ITUC could not avoid politics. Lobbying on legislation was supposed to be its primary purpose, and to that end the executive was called the parliamentary committee. The Home Rule question had a vicarious existence in debates on whether Congress could best fulfil its political role through staying non-political, or through the nationalist Irish Parliamentary Party (IPP), the Labour Representation Committee (from 1906 the British Labour Party), or an Irish Labour party.

Home Rule has attracted little direct attention in Irish labour historiography, being subsumed into the wider debate on socialism and nationalism, on which much was written in the 1970s and 1980s. For the bulk of historians, nationalism was one of those three villains of socialist demonology - the priest, the peasant, and the patriot - who arrested the 'forward march' of Irish Labour. Most who have addressed the topic have focused on James Connolly's socialist republicanism or on Belfast Labour politics, and concluded that Labour was led astray by nationalism. More specifically, it is claimed that Labour could not have endorsed Home Rule because it would have led to a split with Belfast, and because of the social conservatism of the IPP. ${ }^{5}$ These contentions will be challenged here. It will be argued that Belfast Labour was hamstrung by political divisions long before Connolly arrived in the city, and that the ITUC's failure to engage with nationalism was due to mental colonization.

\section{Belfast trades council and the Union}

5 Founded in 1881, Belfast trades council was the biggest and best in Ireland with, in 1897, fifty-six affiliates and 17,500 members; by comparison, Dublin had 12,000 members, and Cork had 2,000. ${ }^{6}$ Belfast was now notorious for sectarian disturbances. Each of the three Home Rule crises saw rioting in the city. Shipyardmen, who prided themselves as the shock-troops of loyalism, were prominent in sectarian riots in 1857, and in attempts to expel Catholic workers in 1864, 1886, 1893, 1901, 1912, and 1920. ${ }^{7}$ Police estimated in 1912 that of nearly 20,000 shipyard workers, 6,000 were active in Unionist clubs and Orange lodges in their workplaces. ${ }^{8}$ But the existential problem for Belfast Labour was not the sectarian divide. Catholic under-representation in skilled occupations meant that Belfast's craft-dominated trade union movement was overwhelmingly Protestant. ${ }^{9}$ The predicament was the contradiction between labour and Labour. Whereas the former was mostly Unionist, and by extension Conservative, the latter's cross-channel role models looked to the Liberals, who were regarded as sympathetic to the IPP. Belfast trades 
council's contact at Westminster was the Liberal-Labour MP Henry Broadhurst. The net effect was that the trades council remained reliant on the affiliation of the weaker unions in textiles and construction. The stronger unions in the metal trades stayed aloof.

William Gladstone's conversion to Home Rule shocked Liberals in Ulster. On 30 April 1886, hundreds of workers attended a rally in Belfast's Ulster Hall at which Liberals rejected Gladstone's Bill. To refute Gladstone's claim that only the upper-classes of Ireland opposed Home Rule, local Liberals despatched a group of trade unionists to Westminster to lobby MPs "supposed to be identified with the interests of the artizans and working classes." While Belfast trades council dissociated itself from the deputation, a letter from council secretary Alexander Bowman to Broadhurst, expressing his personal support for Home Rule, was too much for his colleagues. The ensuing furore compelled Bowman to resign as secretary. The council then recoiled from the political trajectory of British Labour, declining to affiliate to the Labour Electoral Committee set up by the Trades Union Congress in 1887, and hazarding no more than a tentative connection with the successor Labour Electoral Association..$^{10}$ The council escaped the second Home Rule bill relatively unscathed and the crisis would be remembered in Labour folklore for the "green sash" incident. The semi-mythical event occurred when Belfast hosted the 1893 Trades Union Congress and the council marked the close of the congress with a rally on 9 September. The House of Lords had rejected the second Home Rule bill the previous day, and the British speakers were advised to be discreet. Before ascending the platform, a bemused Will Thorne, leader of the National Union of Gasworkers and General Labourers, was persuaded to remove a sash in his union's colours of red, white, and green. The stewards had pleaded that "there's too much green in it." As feared, the meeting was broken up by loyalist heckling about British Labour's sympathy for Home Rule. ${ }^{11}$

7 In 1897, influenced by the new unionism and a damning report on the city's public health, Belfast trades council decided to create its own party and field six candidates in the municipal elections, "all of them", noted the Belfast News-Letter with satisfaction, "on a platform which has more to do with the interests of trade unionism than with the interest of any political party", and all subvented by the trades council to discourage corruption and keep them "non-party." ${ }^{12}$ However, it was an expensive option and socialists like William Walker were less than happy with the Labour councillors' cosy relationship with what he called the "deadhead" city fathers. In 1903, Walker persuaded the trades council to abandon local Labourism and affiliate to the Labour Representation Committee. Walker was currently Ireland's best-known trade unionist, and had ambitions to become an MP. A Unionist and an opponent of the Unionist Party in equal measure, he hoped to unite all of Irish Labour in the British Labour movement. In 1908 he published his only pamphlet The Irish Question. After a review of Irish history, based on the Unionist historian William Lecky, the pamphlet criticised Unionists and nationalists for their obsession with where Ireland was governed from, arguing that the crucial point was that it got good government, and good government was most likely to come from the Labour Party at Westminster. And what better way of strengthening the Union than by joining a British party? But as the Unionists saw it, British Labour was a Home Rule party. Labour leaders Keir Hardie and Ramsay MacDonald pleaded in vain that Walker would be free to advance his own anti-Home Rule views in the party. Matters worsened after the Liberal landslide of 1906. With Home Rule back in the realm of possibility, the once mighty Belfast trades council suffered a steady fall in affiliations, from 63 in 1907, to 40 in 1911, and 32 in 1913. ${ }^{13}$ The decline was all the more remarkable as trades councils in Britain and Ireland were 
becoming more important during these years, as the Liberal government's social reforms gave them a role in campaigning for, providing explanatory public lectures on, and, in some cases, helping to administer legislation through appointments to local committees. The paradox was that the reforms placed the trades council, like the British Labour Party, on the side of the Liberals, and drew it more deeply into the increasingly venomous divisions in British party politics over constitutional change. The forces that made the council more British, made the Unionists more anti-Labour.

\section{The ITUC and Home Rule}

8 Historians have assumed that the ITUC was an important and natural step towards modernity. Mitchell is typical in describing it as "successful...a very model of the British body ${ }^{14}$ The equation of anglicization and progress was characteristic of history as well as historiography, and the ITUC's mindset was conditioned by the extension of British-based trade unions to Ireland in the late nineteenth century. By 1900 there were about 70,000 trade unionists in Ireland - out of some 900,000 wage earners - and at least seventy-five per cent of them were in British-based unions. ${ }^{15}$ Known euphemistically as the " amalgamateds", as so many were prefixed "Amalgamated Society of...", the British unions brought with them their understanding of the appropriate relationship between Labour, society, and politics: one that was all the more pervasive for being part of a general anglicization of Ireland in the decades after the Great Famine. This cultural blanketing entailed the abandonment of Labour-nationalism just at it appeared to be gaining traction under pressure from Michael Davitt. Four 'Lab-Nat' MPs were elected in the 1892 general election including Davitt and two of his nominees. Political neutrality was all the more attractive in the fractious wake of the 'Parnell split', when Davitt went antiParnellite and urban Labour remained passionately Parnellite. But why were the passions so easily forsaken? In England, Labour and nationalism were perceived as dichotomous. English nationalism was identified with the Tories, and Scottish and Welsh nationalism were seen as a threat to the unity of a movement now consolidating on an all-Britain basis. The evidence is plain in the dysfunctional ITUC. Oblivious to the contrasts in employment structure, trade unionism and politics between industrialized Britain and de-industrialized Ireland, the ITUC sought to replicate the British Trades Union Congress. As the president boasted in 1900: "We are not ashamed to admit that we took as our model the procedure and methods which resulted in bringing material benefits for the workers of England during the past quarter of a century (hear, hear)'."16 Trying to copy the British model meant that the ITUC would be primarily an industrial rather than a political body, pursuing its objectives on the basis of union organization, where it was weak, rather than through the IPP, where it would have had some leverage.

9 After years of dithering on the question of political action, Walker arranged for MacDonald and Hardie to address the ITUC in 1903 and seized the moment to move that Congress "heartily recommends to the Trade Unions of this country an immediate affiliation with the Labour Representation Committee to promote the formation of independent labour representation in Ireland." ${ }^{17}$ With the exceptions of 1906 and 1910, similar motions were passed up to 1911, though Belfast alone responded. Throughout this period the parliamentary committee continued to lobby the IPP. Balancing approaches to the Unionists, in 1902 and 1911, did not receive "even an acknowledgment." 18 Numerous IPP MPs had radical associations and John Redmond appealed to Congress regularly for closer 
links with his party. The IPP wanted Labour. Labour wanted political influence. What was the problem? The claim that the ITUC was afraid of losing Belfast is scarcely credible. Belfast residents accounted for twenty-two per cent of delegates to the annual congresses between 1894 and 1914, well below the representation the city might have claimed. These delegates were drawn from forty-five unions, of which just eight had a presence at more than half of the annual congresses. ${ }^{19}$ Moreover, when Irish Labour was given a realistic alternative to the amalgamateds, it embraced the nationalist option with little consideration for Belfast.

\section{Home Rule at last?}

10 Two factors transformed the ITUC's position on the national question in 1911-12. The first was the rise of the Irish Transport and General Workers' Union (ITGWU), which had been founded by "Big Jim" Larkin in 1909. Larkin had come to Ireland in 1907 as agent of the Liverpool-based National Union of Dock Labourers. In 1908 he rejected an invitation to form an Irish union as an unwarranted intrusion of nationalism into Labour affairs. But when he clashed with his union executive, he decided, mirabile dictu, that Irish workers needed Irish unions..$^{20}$ On the ITGWU's admission to Congress in 1910, Larkin pressed for an Irish Labour Party. Walker reacted with a spoiling amendment, to the effect that no funds existed to sustain the project. The amendment was carried 39-18. ${ }^{21}$ In 1911 Walker again moved an amendment to a motion for an Irish party, this time appealing for affiliation to British Labour. His colleague, John Murphy, pleaded: "When they got home rule they could form an Irish Labour Party, but in the meantime let them get all the service they could out of the English Labour Party." 22

After a vitriolic debate, the amendment was carried by 32-29 votes. Delegates from the amalgamateds tended to be hostile to Larkin and the idea of separate Irish organization, and, as yet, the amalgamateds had a safe majority in Congress, accounting for forty-six delegates in 1912, compared to twenty-six from Irish unions - including eight from the ITGWU - and fifteen from trades councils. ${ }^{23}$ But a second factor, the apparent imminence of Home Rule, tipped the scales. The Government of Ireland bill was introduced to parliament on 11 April 1912. Larkin described it as "unjust and inadequate" at Dublin trades council on 22 April, and got the council to reject a motion that it attend a Home Rule convention on the following day. Nonetheless, he welcomed devolution as a step in the right direction. ${ }^{24}$ The ITUC got its first opportunity to respond at the annual Congress in May. Connolly was there as an ITGWU delegate, and his resolution "that the independent representation of Labour upon all public boards be and is hereby included among the objectives of this Congress" was passed by 49-19 votes. ${ }^{25}$ A constitution was framed in 1913, and in 1914 the ITUC became the Irish Trades Union Congress and Labour Party.

In debating the Home Rule bill, most speakers indicated their enthusiasm without endorsing the principle of the bill and breeching the 'no politics' rule. Congress dealt chiefly with the schedules for constituency representation. The bill envisaged a 164 member Irish House of Commons, elected from constituencies based on Dublin University, the six county boroughs, and the thirty-two counties, subdivided in most cases on a geographical basis. Some divisions in Dublin city, Belfast, and Cork city would return three, four, or five MPs, and the others one or two, giving a total of two university seats, thirty-four urban seats, and 128 rural seats. ${ }^{26}$ The expectation that Home Rule would strengthen Labour was moderated by the fear of a farmer-dominated parliament. 
After excoriating farmers and how "Having got the land they turned round and dealt out farmers' justice to the men [agricultural labourers] who had helped them", Larkin declared: "If the towns did not get adequate representation in the new Parliament they would be far worse off under a nominal Home Rule than under an alien Government (...)." Congress demanded that urban areas be grouped in separate constituencies, that the franchise apply to men and women equally, and that the state pay elected members, candidates' expenses, and returning officers' fees. ${ }^{27}$ These demands were reiterated at the 1913 and 1914 Congresses. 28

13 The 1912 Congress saw Larkin elected chairman of a largely Larkinite parliamentary committee, and his more proactive leadership entailed greater use of the IPP to lobby on a variety of legislative measures, including the Government of Ireland bill. ${ }^{29}$ It was an ironic twist, as he loathed Redmond's party and the third Home Rule bill shifted it to a more conservative position on social spending, now that the money would be coming from an Irish exchequer. Relations with the British Labour Party also were transformed by the decision to create an Irish Labour party. Two sets of problems stretched the traditional friendship between Congress and the British Labour Party. First, now that they were becoming more assertive, the Irish were finding the British less helpful. ${ }^{30} \mathrm{At}$ a meeting in Westminster on 15 July 1913, Larkin complained of the party's reluctance to lobby for the ITUC and readiness to take counsel on Ireland from the IPP. ${ }^{31}$ In correspondence with Belfast trades council, MacDonald defended Labour's inaction by saying their hands were tied by "a firm bargain" between the IPP and the Liberal government..$^{32}$ The implication was that if the Irish voted for the IPP, they had to accept the consequences. The second problem concerned the finances of the Irish Labour Party. The Irish wanted the remittance of monies paid by Irish members to the political funds of British-based unions. A joint conference on the subject was held in the library of the Trades Hall, Dublin on 6 September. The British cited various difficulties about the remittance of monies, but Arthur Henderson, who would lead the party from 1914 to 1922, made it clear that were the Irish party to accept a subordinate status to the British party on matters pertaining to the United Kingdom as a whole, then "it would be quite easy to find a solution to the money question". ${ }^{33}$ The Irish replied that their party would be quite separate. The issue remained unresolved. The Dublin lockout of 1913-14 severely worsened relations between Larkin and the British Labour leadership. The latter felt that they had given the ITGWU considerable financial support and received nothing but abuse from Larkin in return. ${ }^{34}$

\section{Partition}

14 In March 1914 the Prime minister, Herbert Asquith, suggested that counties be allowed to opt out of the Government of Ireland Act for up to six years. As the idea of partition had been gaining ground in Unionist circles since 1912, and the Conservatives were likely to be back in power within six years, it was obvious that permanent partition was now a real prospect. Labour united in opposition, fearful that partition would "destroy all our hopes of breaking down sectarian and political antagonisms by the creation of the great Irish Labour Party [and of] uniting the workers of North and South (....)." ${ }^{35}$ The parliamentary committee immediately protested to Asquith, Augustine Birrell, the Chief Secretary for Ireland, and the party leaders at Westminster, and circularized trades councils with an anti-partition 
manifesto. ${ }^{36}$ British Labour replied that party officers agreed with the ITUC on Ulster, adding, ambiguously, that:

anything the Party may ultimately agree to by way of amendment to the present Home Rule Bill will be agreed to in order to make any measure of Home Rule possible and with a view to creating circumstances that will eventually lead to complete Home Rule. ${ }^{37}$

It was not deemed a satisfactory position, and the parliamentary committee again complained that British Labour was taking its cue on Ireland from counsels other than Irish Labour. Congress convened a mass indignation meeting in Dublin on 5 April. What of Belfast?

Walker had set the council on a collision course with Unionism in 1903, when he persuaded it to affiliate to the Labour Representation Committee. While the Belfast Corporation had welcomed the ITUC to the city in 1898 , the trades council did not bother to seek the customary municipal reception for the conferences of the British Labour Party in 1907 or the ITUC in $1908 .^{38}$ In 1912 the mainly Protestant Electrical Trades Union advised the council that to lobby Joe Devlin, Nationalist MP for Belfast West, as appealing to the city's other MPs, would be a waste of time. The council tactfully agreed to raise the matter with Labour MPs. ${ }^{39}$ The general elections of 1910, which led Labour and the IPP to combine to keep the Liberals in power, created a perfect storm for Belfast Labour. The steady withdrawal of pro-Union delegates left the trades council finely balanced between a residue of conservatives, willing to break with the ITUC on the national question, a socialist republican circle grouped around Connolly, who arrived in the city as ITGWU agent in 1911, and, in the middle, a pealing band of Walkerites, determined to postpone the grim choice of siding with Irish Labour or the conservatives to the last minute. The council remained neutral on Home Rule and, with Murphy as secretary, it tried hard to accommodate Unionist sensibilities. An extraordinary illustration is its response to the workplace expulsions in July 1912, when loyalists forced some 3,000 workers out of the shipyards and engineering plants. Unlike previous occasions, the expellees included some 600 Protestants, targeted mainly because of their association with Labour. The council refused to identify with the expelled men. Though Unionist leaders had condemned the violence, the council declined to mention the disturbances in its annual report for 1912, deciding that it was "unexpedient to revive controversy...by any reference in the report." ${ }^{40}$ The Unionist press had long regarded any connection with the ITUC, or British Labour, as tantamount to support for Home Rule, and on Belfast trades council itself, delegates took the same view of the formation of an Irish Labour party. Most of the council's officers at the 1912 Congress opposed an Irish party. ${ }^{41}$ In 1913 the council agreed 19-18 to adjourn the question of affiliation to Congress for twelve months, and, for the first time ever, it would not be represented at that year's Congress. ${ }^{42}$ When, in February 1914, David Campbell, the council's treasurer, proposed participation in an all-Ireland conference on Labour representation, the council agreed to a local conference only, which itself was cancelled when the Electrical Trades Union threatened to disaffiliate. ${ }^{43}$

By contrast, Belfast trades council was united in opposition to partition, though reluctant to take action on it. Characteristically, it avoided the issue until April 1914, when it received the parliamentary committee's invitation to the national protest meeting in Dublin on 5 April. Murphy thought partition would leave "the workers in North East Ulster (...) more than ever in the grip of the sweating employer," but advised caution. The council voted 14-3 to refer the matter to its executive, which resolved that "in the present state of 
divided public opinion, no meeting should be held." ${ }^{44}$ The council meanwhile re-affiliated to the ITUC, and at the annual Congress in June Connolly's resolution condemning partition was passed by 84-2 votes, with eight delegates unrecorded: seventeen delegates from Belfast, three from the rest of Ulster, and four from Britain, attended the Congress. A Cork delegate predicted a commercial boycott of Belfast in the event of partition, and another, with equal prescience, warned: "the North would [then] tell Nationalists to look South for employment (...) bitter divisions would arise." 45 The debate reflected the common opinion - so often attributed to Connolly alone - that partition would weaken Labour or was a device to that end. One of those who voted against the motion said "he was not in favour of exclusion from the point of view of the interest of the Irish worker (...) but he could not support the resolution, because of the men who sent him there." ${ }^{46}$ of three other Belfast speakers, one claimed that Belfast trades council was emphatically against partition, one affirmed his indifference to Home Rule and vehement hostility to exclusion, and one expressed his abhorrence of both.

\section{Conclusion}

18 After sixty years of support for the leading national movement of the day, Irish workers decided they should abjure Home Rule as trade unionists while continuing to believe in it passionately as citizens. It was a graphic illustration of the colonization of Labour thinking by the amalgamateds in the late nineteenth century. The third Home Rule crisis was tortuous for Labour in Belfast, but a catalyst in the political maturation of the ITUC. It ended the self-defeating ordinance against engagement with the national question, and contributed to a partial decolonization of mentalities. It led to the foundation of the Labour Party, albeit on paper only, and made Labour much more cohesive and assertive in pursuit of its legislative agenda, as engagement with the national question generally did. Unfortunately for Labour, the two steps forward in the crisis were followed by one step back. The Ulster question raised the prospect of partition, and the world war created a novel set of challenges for a movement rattled by its defeat in the 1913 lockout and Larkin's departure for the United States in October 1914. The Congress executive, as the parliamentary committee was now called, persisted with its lobbying - over the operation of the National Insurance Act, the schedules of the Government of Ireland Act, and partition, as well as fresh complaints about food shortages and profiteering - only to find the government, the IPP, and the British Labour Party less receptive to its representations in wartime. The executive's difficulties in making progress were reflected in the unprecedented decision to postpone the next annual Congress, and the ITUC did not meet again until August 1916, when the Easter Rising overshadowed its deliberations. Perhaps the major consequence of the anti-climax that followed the third Home Rule crisis was the unpreparedness of Labour to contest the 1918 general election, which would shape Ireland's destiny for the rest of the century. 


\section{BIBLIOGRAPHY}

\section{Archives}

Public Record Office of Northern Ireland, Belfast trades council balance sheets, 1899-1928, D/1050/6/F1.

Ulster University, Magee College, library, ITUC, Annual Reports, 1894-1921; Belfast trades council minutes, 1908, 1911, 1913-14; Dublin trades council minutes, 1912, 1914.

\section{Newspapers}

Belfast News-Letter, 1893.

Irish News, 1912.

\section{Secondary sources}

Black, Boyd, 'Reassessing Irish industrial relations and labour history: the north-east of Ireland up to 1921', Historical Studies in Industrial Relations, 14 (autumn 2002), pp. 45-98.

Boyle, John W., The Irish Labor Movement in the Nineteenth Century (Washington DC, Catholic University of America Press, 1988).

Clarkson, L.A., 'Population change and urbanization, 1821-1911', in Liam Kennedy and Ollerenshaw (eds), An Economic History of Ulster, 1820-1939 (Manchester, Manchester University Press, 1985), pp. 137-157.

Collins, Peter Gerard, 'Belfast trades council, 1881-1921' (D.Phil, University of Ulster, 1988).

Cullen, L.M., An Economic History of Ireland Since 1660 (London, Batsford, 1987).

Farrell, Michael, Northern Ireland: The Orange State (London, Pluto Press, 1976).

Hepburn, Anthony C., 'Work, class, and religion in Belfast, 1871-1911', Irish Economic and Social History, X (1983), pp. 33-50.

Hirst, Catherine, 'Politics, sectarianism, and the working class in nineteenth century Belfast', in Fintan Lane and Dónal ó Drisceoil, Politics and the Irish Working Class, 1830-1945 (London, Palgrave, 2005), pp. 62-86.

Keogh, Dermot, 'Foundation and early years of the Irish TUC, 1894-1912', in Donal Nevin (ed.), Trade Union Century (Cork, Mercier Press, 1994), pp. 19-32.

McCarthy, Charles, Trade Unions in Ireland, 1894-1960 (Dublin, IPA, 1977).

Mitchell, Arthur, Labour in Irish Politics, 1890-1930: The Irish Labour Movement in an Age of Revolution (Dublin, Irish University Press, 1974).

Morgan, Austen, Labour and Partition: the Belfast Working Class, 1905-23 (London, Pluto Press, 1991). 
Munck, Ronnie, 'The formation of the working class in Belfast, 1788-1881, Saothar, 11 (1986), pp. 75-89.

Nevin, Donal (ed.), Trade Union Century (Cork, Mercier Press, 1994).

O'Connor, Emmet and Trevor Parkhill (eds), Loyalism and Labour in Belfast: The Autobiography of Robert McElborough, 1884-1945 (Cork, Cork University Press, 2002).

O'Connor, Emmet, 'Problems of reform in the Irish Trades Union Congress, 1894-1914', Historical Studies in Industrial Relations, no.23/24, (spring/autumn 2007), pp. 37-59.

O'Connor, Emmet, Big Jim Larkin: Hero or Wrecker? (Dublin, UCD Press, 2015).

Patterson, Henry, Class Conflict and Sectarianism: The Protestant Working Class and the Belfast Labour Movement, 1868-1920 (Belfast, Blackstaff Press, 1980).

Patterson, Henry, 'Industrial labour and the labour movement, 1820-1914', in Liam Kennedy \& Philip Ollerenshaw (eds), An Economic History of Ulster, 1820-1939, (Manchester, Manchester University Press, 1985), pp. 158-183.

Purdie, Bob 'Riotous customs: the breaking up of socialist meetings in Belfast, 1893-1896', Saothar 20 (1995), pp. 32-40.

Thorne, Will, My Life's Battles (London, George Newnes, 1927).

\section{NOTES}

1. Labour refers to trade union organizations and socialist parties, and labour to all waged labour. Similarly, to distinguish them from trade unionists, supporters of the Union with Britain will be referred to as Unionists, whether members of the Unionist party or not.

2. See L.A. Clarkson, "Population change and urbanization, 1821-1911", in Liam Kennedy and Ollerenshaw (eds), An Economic History of Ulster, 1820-1939 (Manchester, Manchester University Press, 1985), pp. 137-54; Michael Farrell, Northern Ireland: The Orange State (London, Pluto Press, 1976), p. 18; L.M. Cullen, An Economic History of Ireland Since 1660 (London, Batsford, 1987), pp. 16-62.

3. Ulster University, Magee College, library (UUMC), ITUC, Annual Report (1894), pp. 3-5, Annual Report (1895), p. 12.

4. UUMC, ITUC, Annual Report (1900), p.14.

5. The two histories of the ITUC, Charles McCarthy, Trade Unions in Ireland, 1894-1960 (Dublin, IPA, 1977) and Donal Nevin (ed), Trade Union Century (Cork, Mercier Press, 1994), say little on Home Rule. Austen Morgan, Labour and Partition: the Belfast Working Class, 1905-23 (London, Pluto Press, 1991); Henry Patterson, Class Conflict and Sectarianism: The Protestant Working Class and the Belfast Labour Movement, 1868-1920 (Belfast, Blackstaff Press, 1980); Boyd Black, "Reassessing Irish industrial relations and labour history: the north-east of Ireland up to 1921", Historical Studies in Industrial Relations, 14 (autumn, 2002), pp. 45-85; and Peter Gerard Collins, "Belfast trades council, 1881-1921" (D.Phil, University of Ulster, 1988) are all highly critical of Connolly and nationalism.

6. Patterson, Class Conflict and Sectarianism, p. 40.

7. Catherine Hirst, "Politics, sectarianism, and the working class in nineteenth century Belfast", in Fintan Lane and Dónal Ó Drisceoil, Politics and The Irish Working Class, 1830-1945 (London, Palgrave, 2005), pp. 62-86; A.C. Hepburn, "Work, class, and religion in Belfast, 1871-1911", Irish Economic and Social History, X (1983), p. 50.

8. Patterson, Class Conflict and Sectarianism, pp. 88-9; Henry Patterson, 'Industrial labour and the labour movement, 1820-1914', in Liam Kennedy \& Philip Ollerenshaw (eds), An Economic History of 
Ulster, 1820-1939, (Manchester, 1985), p. 178; and Ronnie Munck, "The formation of the working class in Belfast, 1788-1881", Saothar, 11 (1986), p. 84.

9. For the composition of the city's workforce see Black, "Reassessing Irish industrial relations and labour history: the northeast of Ireland up to 1921", pp. 45-97.

10. Collins, "Belfast trades council, 1881-1921" p. 42; John W. Boyle, The Irish Labor Movement in the Nineteenth Century (Washington DC, Catholic University of America Press, 1988), p. 157.

11. Will Thorne, My Life's Battles (London, George Newnes, 1927), pp. 158-159; Belfast News-Letter, 11 September 1893, and Bob Purdie, "Riotous customs: the breaking up of socialist meetings in Belfast, 1893-1896”, Saothar, 20, pp. 32-40; Emmet O'Connor and Trevor Parkhill (eds), Loyalism and Labour in Belfast: The Autobiography of Robert McElborough, 1884-1945 (Cork, Cork University Press, 2002), pp. 9, 36, 42.

12. Boyle, The Irish Labor Movement in the Nineteenth Century, p. 168. A trades council is an organisation gathering local trade unions; the number of affiliations asseses the number of unions which had joined the council.

13. Public Record Office of Northern Ireland, Belfast trades council balance sheets, 1899-1928, D/1050/6/F1.

14. Arthur Mitchell, Labour in Irish Politics, 1890-1930: The Irish Labour Movement in an Age of Revolution (Dublin, Irish University Press, 1974), p. 17. See also Dermot Keogh, "Foundation and early years of the Irish TUC, 1894-1912", in Donal Nevin (ed.), Trade Union Century (Cork, Mercier Press, 1994), pp. 19-32, for a defence of the ITUC against criticisms of the present author.

15. Boyle, The Irish Labor Movement in the Nineteenth Century, pp. 125-6. On the anglicization of Labour see Emmet O'Connor, "Problems of reform in the Irish Trades Union Congress, 1894-1914" Historical Studies in Industrial Relations, no.23/24, spring/autumn (2007), pp. 37-59.

16. UUMC, ITUC, Annual Report (1900), p. 6.

17. UUMC, ITUC, Annual Report (1903), p. 54.

18. UUMC, ITUC, Annual Report (1902), pp. 24-5; Annual Report (1903), p. 31; Annual Report (1911), p. 18.

19. Based on ITUC Annual Reports (1894-1921).

20. Emmet O'Connor, Big Jim Larkin: Hero or Wrecker? (Dublin, UCD Press, 2015), p. 45.

21. UUMC, ITUC, Annual Report (1910), pp. 48-9.

22. UUMC, ITUC, Annual Report (1911), pp. 39-42.

23. UUMC, ITUC, Annual Report (1912), pp. 61, 77-9.

24. UUMC, Dublin trades council minutes, 22 April, 17 June 1912.

25. UUMC, ITUC, Annual Report (1912), pp. 12-19.

26. UUMC, ITUC, Annual Report (1914), pp. 27-30.

27. UUMC, ITUC, Annual Report (1912), pp. 51-3.

28. UUMC, Dublin trades council minutes, 20 April 1914; ITUC, Annual Report (1913), pp. 64-9; Annual Report (1914), pp. 63-4.

29. UUMC, ITUC, Annual Report (1913), pp. 3-12.

30. Ibid., pp. 22-3.

31. UUMC, ITUC, Annual Report (1914), pp. 1-4.

32. UUMC, Belfast trades council minutes, 7 December 1911.

33. UUMC, ITUC, Annual Report (1914), pp. 5-6.

34. O'Connor, Big Jim Larkin, pp. 135-8.

35. UUMC, ITUC and Labour Party, Annual Report (1916), p.13.

36. UUMC, Belfast trades council minutes, 2 April 1914.

37. UUMC, ITUC, Annual Report (1914), p. 18.

38. UUMC, Belfast trades council minutes, 18 April, 7 May 1908.

39. UUMC, Belfast trades council minutes, 7 March 1912; Irish News, 8 March 1912.

40. Morgan, Labour and Partition, pp. 127-39 provides the most detailed account of the expulsions. 
41. UUMC, ITUC, Annual Report (1912), pp. 12-19.

42. UUMC, Belfast trades council minutes, 14 March \& 3 April 1913.

43. Morgan, Labour and Partition, p. 164.

44. UUMC, Belfast trades council minutes, 2 April 1914; Collins, "Belfast trades council, 1881-1921", p. 194.

45. UUMC, Annual Report (1914), p. 72.

46. UUMC, ITUC, Annual Report (1914), pp. 70-3, 108-10.

\section{ABSTRACTS}

The Home Rule question has been neglected in labour historiography, which has focused instead on the wider issue of socialism and nationalism, James Connolly's writings, and the difficulties of Labour in Unionist Belfast. Most academic historians have regarded nationalism as a barrier to the evolution of Labour politics and seen the Irish Parliamentary Party as socially conservative. It will be argued here that Labour's disengagement from Home Rule politics was due to mental colonization, that Labour-nationalism would have been a productive option, and that the third Home Rule was positive for Labour, outside Belfast. It will also be argued that the problems of Labour in Belfast were created by Unionism rather than nationalism or sectarianism.

La question du Home Rule a été négligée par l'historiographie du mouvement travailliste/ ouvrier, qui s'est consacrée plutôt aux plus larges problèmes du socialisme et du nationalisme, aux écrits de James Connolly et aux difficultés des travaillistes dans les quartiers unionistes de Belfast. La plupart des historiens ont considéré le nationalisme comme un obstacle à l'évolution des politiques travaillistes et ont perçu le parti parlementaire irlandais comme conservateur sur les questions sociales. Cet article démontrera que le désengagement travailliste de la campagne politique pour le Home Rule était lié à une colonisation mentale, qu'une alliance entre travaillisme et nationalisme aurait été une option productive et que le troisième projet de loi sur l'autonomie de l'Irlande était positif pour le travaillisme, à l'exception de Belfast. L'article démontrera également que les difficultés rencontrées par le travaillisme à Belfast furent davantage crées par l'Unionisme que par le nationalisme ou par les tensions religieuses.

\section{INDEX}

Mots-clés: mouvement ouvrier, nationalisme, unionisme-Belfast, partition, syndicats

Keywords: Labour, nationalism, unionism-Belfast, partition, trade unions

\section{AUTHOR}

\section{EMMET O'CONNOR}

Emmet O'Connor is a senior lecturer in the School of History in Ulster University. He is a former editor of Saothar, journal of the Irish Labour History Society, and has published widely on labour history including Syndicalism in Ireland 1917-1923 (Cork University Press, 1988); Reds and the Green: 
Ireland, Russia, and the Communist Internationals, 1919-43 (Dublin, UCD Press, 2004); A Labour History of Ireland, 1824-2000 (Dublin, UCD Press, Second edition 2011); and Big Jim Larkin: Hero or Wrecker? (Dublin, UCD Press, 2016). At present he is working on a study of the Irish in the Spanish Civil War.

Emmet O'Connor est enseignant-chercheur à la faculté d'histoire de l'Université d'Ulster. Il a été rédacteur en chef de Saothar, la revue de l'Irish Labour History Society, et a publié de nombreux articles et ouvrages sur l'histoire syndicale / l'histoire du mouvement ouvrier, parmi lesquels Syndicalism in Ireland 1917-1923 (Cork University Press, 1988); Reds and the Green: Ireland, Russia, and the Communist Internationals, 1919-43 (Dublin, UCD Press, 2004); A Labour History of Ireland, 1824-2000 (Dublin, UCD Press, Second edition 2011); et Big Jim Larkin: Hero or Wrecker? (Dublin, UCD Press, 2016). Il travaille actuellement sur les Irlandais dans la Guerre d'Espagne. 